\title{
Learning from Fiction to Change our Personal Narratives
}

\author{
ANDREW J. CORSA \\ Lynn University, Boca Raton, Florida, USA
}

\begin{abstract}
Can fictional literature help us lead better lives? This essay argues that some works of literature can help us both change our personal narratives and develop new narratives that will guide our actions, enabling us to better achieve our goals. Works of literature can lead us to consider the hypothesis that we might beneficially change our future-oriented, personal narratives. As a case study, this essay considers Ben Lerner's novel, 10:04, which focuses on humans' ability to develop new narratives, and which articulates a narrative that takes into account both everyday life and large-scale issues like the global, environmental crisis.
\end{abstract}

Keywords: Narrative; fiction; Ben Lerner; autofiction; global warming; living option.

When I read Ben Lerner's (2014) book, 10:04: A Novel, I felt compelled to reflect on my capacity to create new, future-oriented personal narratives for myself. In the course of my reflections on 10:04, I developed a question that became the focus of this essay: Can fictional literature help individuals create new future-oriented narratives for themselves that they might not have created otherwise, and might those narratives help them lead better lives in which they are more successful at achieving their goals?

The first part of this essay provides a general background about personal narratives, giving a sense of what theorists such as Arran Gare and J. David Velleman have suggested about the role future-oriented personal narratives play in guiding our actions, and why changing our personal narratives might sometimes help us to more successfully pursue our goals. The second part of this essay argues that works of literature can lead us to consider changing our personal narratives in ways that we might not have considered otherwise. Building on the work of 
theorists such as Catherine Z. Elgin and David Novitz, this essay argues that, as a result of reading works of literature, some readers might consider the hypothesis that adopting certain narratives, like those described by the works of literature, might help them to better achieve their goals. This essay argues that, after reflecting on certain works of literature, some readers might consider the possibility of adopting a new narrative to be a genuine, living option. While many theorists have argued that literature can have a positive impact on readers, this paper's discussion of narratives becoming living options is unique.

To provide a case study, this essay reflects on 10:04, which focuses in part on environmental concerns like global warming. This essay argues that, after reading 10:04, some readers might develop for themselves, and consider, the hypothesis that they should develop new personal narratives that better balance everyday life with a concern for the earth's environmental crisis. Part four examines how 10:04 can effectively lead readers to reflect on the ways in which fictional literature helps them create new personal narratives.

\section{Personal narratives}

This essay understands narratives as structured stories which people tell either themselves or others, which may be either fictional or trueto-life (cf. Goldie, 2012: 2). Narratives are structured with a beginning, a middle, and end, and reveal causal connections between many of the events they describe (Goldie 2012: 11-17; Robinson 2014: 310-312). As Grace Clare Robinson notes, while many narratives are expressed verbally, they need not be, and narrative content, which is the same as the "basic structure" of a story, can "survive translation" into different media (Robinson 2014: 311; cf. Carr 1986: 62-63). Robinson claims, for instance, that it would be possible for the narrative of Romeo and Juliet to be translated into a silent dance. Peter Goldie contends that narratives need not be publicly expressed; they can be "thought through in narrative thinking" (2012: 2-4; cf. Carr 1986: 62-63). People routinely develop narratives in their minds before they articulate them to others, and often never choose to publicly articulate their mental narratives.

Arran Gare claims that people often make sense of the world through narratives-through the stories that we tell ourselves and others (1995: 62; cf. MacIntyre 2008: 216). David Carr maintains that while some writers of literature articulate fictional narratives, humans in general are often inclined to organize the events of their own real lives into narratives (1986: 4-5; cf. Bruner 1991: 18; Kirkpatrick 2014: 60; Bruner and Kalmar 1998: 318). Many humans also routinely construct narratives about what their own futures might be like-stories about what they intend or hope to do. ${ }^{1}$ According to both Gare and

${ }^{1}$ For discussions of "narrative thinking about one's future," see: Goldie 2012: Chapter 4. 
Carr, we routinely construct such future-oriented narratives when we pursue "long-term undertakings" such as "writing a book, getting an education, [or] raising a child" (Carr 1986: 54 and 61; cf. Gare 2001). ${ }^{2}$

Humans do not wait until their undertakings are complete before constructing narratives about them. Instead, we build narratives to help us complete the undertakings while they are ongoing. Carr writes that our complex undertakings can be understood "as a process of telling ourselves stories, listening to those stories, and acting them out or living them through" (1986: 61; cf. Gare 2001; MacIntyre 2008: 212; Corsa 2018: 243-244). The narratives we tell ourselves about our futures guide our actions. As Goldie notes, sometimes when we construct narratives in our minds about actions we intend to perform, our "narrative thinking might turn into a plan do just that" (2012: 88). As J. David Velleman puts it, a person might sometimes "narrate ahead of himself and then follow a career that reflects his story" (Velleman 2005: 63).

Velleman contends that, by composing narratives about how we hope to act, we become more likely to act as we hope (Velleman 2005: 65; cf. Tollefsen and Gallagher 2017: 101-103). At the end of a day of work, you might say to yourself, "I am going home now," and construct a mental narrative in which you in fact, go home-not because you were already going to leave, but in order to prompt yourself to do so. Velleman notes that there are many cases in which expressing that you will perform an action makes you more likely to perform it. For example, he refers to a psychological study, performed by Greenwald, Carnot, Beach and Young (1987), which indicates that subjects who predict they will vote are significantly more likely to vote than those who are never asked to make a prediction (Velleman 2005: 65-66). Carr maintains that by telling ourselves future-oriented stories about how we will complete our undertakings, we can also: remain clear about how our current activities relate to our goals; clarify to ourselves what we will need to do next; better determine if we have gone off track; and better figure out if we need to change our strategies to address changing circumstances (1986: 61, 71 and 87; cf. Corsa 2018: 243-244). The stories we tell ourselves can even affect our view of the world; Jerome Bruner and David A. Kalmar contend, for example, that if we construct

${ }^{2}$ Unlike several theorists discussed, this essay does not argue in support of the claim that selves are constituted by narratives. While this essay's contentions are consistent with this claim and would fit well in many theories that support it, many objections to this claim are not objections to this essay's arguments. Suppose the claim that selves are constituted by narratives is false. Also suppose it is possible to have coherent self-experience without "understanding and living out our lives in storied ways" (Hutto 2016: 29). Nonetheless, this essay's arguments could still be sound. It could still be true that: people often make sense of the world through narratives; many people construct narratives about their futures; these narratives change their actions; and developing new personal narratives might sometimes help people achieve their goals. Daniel D. Hutto, who rejects strong narrativism, nonetheless maintains that people often make use of narratives in their efforts to shape their lives (Hutto 2016: 25). 
personal narratives in which we are "victims," we will likely see others as more agentive than if we saw ourselves as "agents," instead (1998: 317).

The way that people think of their personal narratives, in real life, does not closely resemble the way that critics think of narratives in works of literature (cf. Lamarque 2007: 118; Schechtman 2011: 413). As Peter Lamarque notes, when critics read works of literature, they often take chance events and small details to have symbolic significance, to foreshadow future events, or to help develop themes (Lamarque 2007: 123-125). A critic might say that an event in a literary narrative, which characters view as a chance accident, needed to happen in order for the author to effectively develop a theme, a character arc, or a plot (Lamarque 2007: 124-127). Now consider real-life personal narratives. Lamarque notes that it would be a mistake to frequently attribute symbolic or thematic significance to small details or chance events in our lives (Lamarque 2007: 131; cf. Schechtman 2011: 411-413). Likewise, it would be an error to think that every chance event needed to happen, in order for our lives to take a shape they were "supposed" to have (Lamarque 2007: 131; cf. Schechtman, 2011: 411-413).

Rather, as Marya Schechtman indicates, while the way we reflect on our real-life narratives should partly resemble the way that critics think of literary narratives, it should also partially resemble the way that authors and characters view their narratives (2011: 413). In many works of literature, characters do not think of small details or chance events as having symbolic or thematic significance, or as needing to happen in order to develop a specific theme. Like characters, it would not be appropriate for us to think of the small details or chance events in our lives in these ways, either. Also like most characters, real people do not have complete control over their narratives; we cannot completely determine how other people will react to us (Schechtman 2011: 413), or change what actually happened in our past (cf. Vice 2003: 103). Yet, as Samantha Vice notes, it would be mistaken to think that we, in real life, are like characters in a stories that have already been written, and that we need to stick to certain roles or plot-lines (Vice 2003: 103). Instead, as Schechtman indicates, in some respects we need to view our lives like authors view stories that are not yet finished; we have some control over our future narratives insofar as we are responsible for our choices (2011: 413-414). Finally, like critics, we can reflect on the significance of our choices as authors of our own personal narratives, and doing so might help us to make better choices in the future.

Many of the theorists discussed above agree that the narratives we construct about ourselves have an influence on the actions we take, our perspectives, and whether we are successful at achieving our goals. Our lives shape our stories, but our stories also shape our lives (Velleman 2005: 64). It follows that sometimes it might be prudentially valuable for individuals to change the personal narratives they tell 
themselves or others, in order to change their future behaviors or outlook. That way, they might more effectively reach their goals or, alternatively, strive for different goals. Gare writes that individuals who choose to "question the stories they have been socialized into" and live their lives in accordance with "alternative versions of these stories" that they have deliberately chosen for themselves "take responsibility for their lives" and "are the creative agents of culture, society and history” (2002: 97; cf. Gare 2001; Kirkpatrick 2014: 65; Carr 1986: 92-9; Bruner and Kalmar 1998: 326).

\section{Learning from literature}

We might sometimes be unable to create new narratives that would better help us achieve our goals because we are unaware of the kinds of narratives we could create. When reflecting on what options are open to us, we are often constrained by past experiences, by emotional dispositions, and by personal character (Goldie 2012: 89).

As Catherine Z. Elgin notes, people routinely engage with a huge quantity of information; objects of perception and life experiences have a vast number of properties. We inevitably have to ignore some information and some properties, focus substantially on others, and attend to only some possible patterns (Elgin 2007: 44). Elgin writes that we are often unaware of how much information we ignore and how we choose to focus our attention; rather "we adopt familiar orientations and judge by received standards" and we have "cognitive default settings that we invoke unthinkingly" (2002: 2). We tend to focus on properties, categories, and patterns based on our established habits and "time-honored methods" (2007: 46). When we determine how to act, make plans, and create future-oriented personal narratives, we rely on the information, categories and patterns on which we focus. Since we are often unaware of the information and patterns we ignore, "we are blind to the mistakes we might be making and the opportunities we might be missing" (Elgin 2007: 46). We might fail to develop better future-oriented narratives for ourselves, because we are limited by our outlooks, and we are unaware of the ways in which we could change them. Certainly, it is possible for us to meet and observe people we deem successful and admire, but without understanding the very different ways in which they categorize what they perceive-and the different ways in which they focus on and ignore information-we might sometimes not understand the personal narratives they developed for themselves, ${ }^{3}$ or how we might develop and live according to related narratives.

Even if we do understand what sorts of future-oriented personal narratives we might practically develop for ourselves, we might not think of some of those narratives as "living," genuine options. Reflect-

${ }^{3}$ Compare with the different but related considerations in: Gallagher 2014: 602603 and 606. 
ing on the philosophy of William James, Alexis Dianda maintains that a living hypothesis is one that must cohere with a person's beliefs, cultural context, and history (2018: 651-652; James 1898). Catholics, but not atheists, might accept as "living" the hypothesis that it would be beneficial to create a future-oriented personal narrative according to which they attend Catholic mass regularly for the rest of their lives. Likewise, Goldie notes that our character traits constrain what options and future-oriented narratives we consider "living"; after all, a "considerate person wouldn't dream of leaving someone in the lurch" and "the punctual person just wouldn't think of dawdling" (2012: 89). Additionally, a person might choose not to develop or try to live according to certain future-oriented narratives, believing that they could not possibly live according them, even when they really could. There is a risk that people might sometimes reject personal narratives that would actually help them to better achieve their goals or be the kind of people they would most like to be.

Some works of fictional literature, however, can help individuals to better recognize what kinds of personal narratives they might develop for themselves, and to recognize those narratives as genuine, living options for them. This essay does not contend that readers routinely use fictional literature this way, or that all works of literature could be effectively used like this. Rather, it maintains that, after reading some works of fictional literature, some readers might reflect on the hypothesis that developing a different personal narrative might help them to live better. ${ }^{4}$ Some works of literature might also help readers to recognize that the hypothesis on which they reflect is living and possible. ${ }^{5}$

Obviously, fictional literature includes many statements that are not true of the real world. Even when literature includes true statements, readers often should not consider them true of the real world without additional evidence. For example, as Elgin notes, Moby Dick includes truths about what methods are effective for harpooning a whale. Yet, without additional evidence, a reader could not know when the book's author has taken liberties with the truth, could not know which of its claims are true and which false, and ought not consider any of its claims about whaling true of the real world without additional evidence (Elgin 2007: 43).

Novitz proposes that we can treat fictional literature as offering hypotheses about what the world is like, which readers can then test out in reality, and either confirm or reject based on life experience, or based on whether each hypothesis "coheres with their established beliefs" (Novitz 1984: 56-57; cf. Vidmar 2013: 178-179; Elgin 2007: 53).

${ }^{4}$ While Nussbaum does not discuss hypotheses or narratives in these ways, this essay was influenced by her arguments about how works of literature help us to grapple with the question: "How should one live?" See: Nussbaum 1990. Nussbaum frames this question on p. 50 .

${ }^{5}$ For discussions of how William James thinks people can transition from seeing a hypothesis as dead to seeing at as living: Dianda 2018: 656-659. 
In some cases, a reader might study the real world, in order to determine whether a fiction's hypothesis is true. Or, as David Davies indicates, if a work of fictional literature indicates a pattern underlying the experiences of its characters, we might "test" the hypothesis that this pattern also belongs to real-life experiences by reflecting on whether we "feel" that the pattern is actually apparent in the real world; we might trust such feelings because we take them to be based on "tacit or unarticulated knowledge" of the world we already had prior to reading (Davies 2007: 44; cf. Vidmar 2013: 179 and 190; Kivy 2006: 107-108). Peter Kivy further contends that works of literature can sometimes help readers to see certain hypotheses as "living" rather than "dead" (2006: 101-102; cf. Vidmar 2013: 190). What this essay adds is that, after reading some works of fictional literature, some readers might consider hypotheses about personal narratives they might want to adopt and realize that these hypotheses are living.

How do fictions do this? They present us with narratives very different from our own, and after reading them, we might sometimes develop and consider the hypothesis that, if we were to change our narratives to either more-closely or less-closely resemble the narrative described, we might lead better lives, ourselves. Works of literature can sometimes give us a sense of how we might see the world differently, and of the kinds of narratives we might construct for ourselves if we did.

Fictional literature often presents narratives involving characters who focus on different properties of objects and situations from those we typically focus on, and who have different skills of pattern recognition from ours. Literature often enables readers to take on the perspectives and phenomenology of these characters (Farrell 2007: 256; cf. Elgin 2007: 51). Elgin proposes, for example, that if we took on the "morally impeccable point of view" of the character Fanny Price in Austen's Mansfield Park, and learned to "focus on the sorts of factors" her view discloses, we might be able to "increase our own moral sensitivity" in everyday life (2007: 52). This essay adds that, having changed our perspective, we might also consider constructing new, future-oriented narratives for ourselves that we may not have considered, otherwise. Elgin writes that even if a character's perspective is not accurate, it can still be rewarding to adopt it. For instance, she notes that, by taking on the view of Holden Caufield in Salinger's The Catcher in the Rye, we might come to recognize things as phony that we might otherwise fail to rightly see as hypocritical (Elgin 2007: 52).

Without the help of literature, it might often be difficult to fully understand perspectives that are very different from our own. According to Karen Simecek, a perspective is: "a set of implicit beliefs, commitments, and values" that determines "not only what information becomes the focus of our thinking; i.e. what we will bring to the fore, but how we will organize that information in bringing those features to the fore" (2015: 501). Elisabeth Camp notes that a perspective or- 
ganizes our thoughts, making some features of the world "stick out in our minds" while others do not (2009: 111); changing perspective can change what we focus on, how we categorize what we perceive, and the patterns we notice.

In real life, we engage in what some theorists call mindreading - attributing mental states to people we encounter and coming to believe that they have specific beliefs and feelings (cf. Goldman 2005; Gallagher 2011: 21-22; 2012: 356 and 359; 2014: 601). But, while it might sometimes be possible to have a sense of some of people's mental states, it is often difficult to fully grasp their perspectives. It is difficult to understand just how people think of their circumstances, on what details and information they focus, or the kinds of patterns they notice. Suppose we try to imaginatively put ourselves in another person's shoes, aiming to set aside our own mental states and substitute those of the target (cf. Goldman 2005: 86; cf. 79-81). Then suppose we ask ourselves how we would think of the circumstances the target faces, were we in his/her shoes. How reliably can we set aside our own mental states and adopt someone else's? How often would we mistakenly suppose that the target would perceive and approach his/her circumstances much like we would approach them if we faced those circumstances, ourselves, when in fact the target, whose perspective is radically different from ours, would approach circumstances much differently (cf. Gallagher 2012: 363-364 and 370; 2014: 602-603)? As Shaun Gallagher remarks, if we rely on our own experiences and imagination, it would be difficult to take into account other people's vast diversity of beliefs, perspectives, and experiences (ibid.).

Yet literary narratives can give us an expanded understanding of diversity, introducing characters who are unlike anyone we have met, events we have never experienced, and locations we have never visited (Nussbaum 1990: 47-48). Literary narratives provide a sense of how people very different from us might behave in a variety of circumstances, what reasons they might have for their actions, and how they might feel (cf. Gallagher 2011: 31-33; 2012: 371). Gallagher maintains that an education in narratives can provide us with background knowledge about people very different from us, on the basis of which we can better understand the perspectives of people in real life and better predict how they might think, feel and act (2011: 31-34; 2012: 371-372; 2014: 605-606). We can also take works of fictional literature as offering hypotheses about which actions would be considered socially acceptable in a variety of circumstances, how we, ourselves, could choose to act in those circumstances, and about what would constitute good reasons for different actions (cf. Gallagher 2012: 371; 2014: 605-606). When we better understand what actions are possible and acceptable in a variety of circumstances, we gain a better sense of possible future-oriented personal narratives we could develop for ourselves.

As Simecek notes, literary narratives often draw attention to specific details of the characters they describe, suppress other details, categorize 
and compare characters, and encourage readers to adopt specific perspectives of characters (2015: 502-504 and 508). The details on which works of literature focus, and the categorizations they make, might be very different from the details and categorizations on which readers would focus if they encountered people like the works' characters in real life (Camp 2009: 117). Camp indicates that once readers gain a sense of the different details on which they could focus, categorizations they can make, and perspectives they could take, they might change what they focus on in the real world and how they interpret what they encounter (Camp 2009: 117). Even if we cannot adequately understand or adopt the perspectives of some real people we meet, we might still be able to at least partially understand and adopt the perspectives offered by some fictional literary narratives. These new perspectives, in turn, might enable us to develop new personal narratives for ourselves.

Kivy notes that if a deep and complex fictional character that we care about and understand holds an opinion, then perhaps we will take that opinion more seriously (Kivy 2006: 113). This essay adds that if fictional characters like that have narratives very different from our own, we might be more inclined to consider the hypothesis that we should create future-oriented narratives more like theirs. We might also be more likely to see this hypothesis as living. Likewise, when we appreciate these characters' distinctive perspectives, we might better understand how we would need to see the world in order to live according to future-oriented narratives like theirs. Also, as Novitz indicates, when we read about these characters applying practical or intellectual strategies to achieve their goals, and vividly imagine them doing so, we might reflect on the hypothesis that similar strategies might be able to help us reach similar goals-goals that we might otherwise have thought were impossible for us (1984: 49 and 57-60).

It is beyond the scope of this essay either to carefully explore when readers would be justified to consider adopting new personal narratives in response to reflecting on hypotheses raised by works of fiction, or to explore how someone who reads numerous works of fiction might reasonably choose which of their hypotheses to test out in real life. Imagine a reader who is wondering which hypotheses to test out in real life, and is confident that testing out any of them would not be immoral. ${ }^{6}$ Perhaps future research could consider whether it is justifiable for a reader like this to consider choosing to test out just those hypotheses the reader feels are particularly emotionally compelling. How often do even scientists who apply good research methodology rely on emotions and gut-feelings when determining which hypotheses to test? ${ }^{7}$ Separately, it is also beyond the scope of this essay to provide an account

\footnotetext{
${ }^{6}$ For content relevant to the problem of determining which hypotheses would be moral, see: Nelson 2001: 41-45 and 51-52.

${ }^{7}$ Consider Alexander Klein's reflections on William James's approach to the role of one's passions when selecting which hypotheses to consider (2015: 84-92).
} 
of exactly what a work of literature and reader would need to be like, for the work to prompt the reader to consider adopting a new personal narrative. Yet, in the next section, this essay will consider an example of a work of literature-10:04 - that can prompt readers to consider the hypothesis that they should change their personal narratives.

\section{A Case Study: Learning from Lerner's 10:04}

Ben Lerner's novel, 10:04, is narrated by a character who, like Lerner himself, is an author living in Brooklyn and who describes his pressures and life experiences during the time in which he hopes to write a new novel. The narrator describes a number of personal challenges he faces: he has just heard from his doctor that he has a potentially life-threatening condition, and his best friend has asked if she could use his sperm for artificial insemination. The narrator also focuses on his day-to-day social interactions, and describes trivial concerns of day-to-day life that can nonetheless induce stress. For example, the narrator at one point chaperones a boy on a visit to a museum; Lerner provides a four-page description of a five-minute scene in which the narrator needs to find a restroom, panics about leaving the child on his own, speaks with the boy about where to wait for him, and then panics when the boy is not exactly where he had promised to remain (2014a: 149-152).

David James mentions Lerner as an example of a "localist" writer (James 2017: 133) - the kind of author who focuses substantially on "quotidian circumstances" and the "fiction of local life" (James 2015: 47). Yet James is careful to note that localist fictions, like 10:04, can nonetheless engage with "worldly concerns" (2015: 49), and can explore the tensions and relations between local and global issues. As much as 10:04 focuses on the day-to-day, localized life of its narrator, it also focuses on global concerns, like global warming, and reflects on great expanses of time.

Ben De Bruyn describes 10:04 as an "example of a contemporary climate-change novel" because, while it provides "a remarkably realist attention to everyday life," it frequently reflects "on our increasingly unrecognizable planet" and its narrator's anxieties about global environmental crises (2017: 951; cf. Gibbons 2019a; 2020: 1). The narrator, who is worried about global warming, refers to the weather's "unseasonable warmth" repeatedly throughout the novel (2014a: 3, 32, 63, 66, 107, 164, 206, 213, 221, and 231; cf. Gibbons 2019a; Gibbons 2020: 10). Likewise, the narrator often imagines New York City either as "underwater" or as "sinking" (2014a: 4, 40, and 153; Gibbons 2020: 10). The narrator has a conversation with a boy-the same he chaperoned at the museum - who has had a dream that "the buildings all freeze up after global warming makes an ice age" (2014a: 13), and the narrator empathizes with the boy whom he says, "like me, tended to figure the global apocalyptically" (2014a: 14; cf. Gibbons 2019a: 2020: 10). 
The novel's narrative is bookended by hurricanes Irene and Sandy, which, as Alison Gibbons notes, grounds the novel in historical time (2019a; cf. 2020: 5-6; De Bruyn 2017: 953). As De Bruyn indicates, the novel's narrative also frequently refers to "the inhuman timeframes of paleontology and astronomy” (De Bruyn 2017: 953). For example, the narrator reflects at substantial length upon his recognition that the brontosaurus might never have existed and that Pluto might not be a planet-recognitions that challenge his "remembered sense of both galactic space and geological time" (Lerner 2014a: 11; De Bruyn 2017: 953). Likewise, while the narrator reflects at length on the specific events of his day-to-day life, he sometimes considers the broader contexts and global networks that have made events in his life possible. When he eats octopus at a restaurant, for instance, he briefly muses about "the rhythm of artisanal Portuguese octopus fisheries ... the mercury and radiation levels of the sashimi and the chests of the beautiful people in the restaurant-coordinated, or so it appeared, by money" (Lerner 2014a: 156; De Bruyn 2017: 957).

The narrator in 10:04 might serve as an example to readers of how they might choose to lead their everyday lives, all the while aware of the environmental crises affecting the planet. Each of us is going to continue to lead a full life, complete with everyday social interactions and personal challenges. How might we best think about how to lead our local lives, even as we are aware of global crises? Lerner implies that he had questions like this-if not this exact question-in mind, himself. In an interview, he remarks:

I can see why, if I, the historical person, choose to write a book that's set in Brooklyn that talks about book advances and eating Bluefin tuna or whatever, that it's automatically in the category of the self-absorbed ... The book wants to acknowledge all of that as an attempt to see what spaces for healing can exist, as opposed to the model of fiction that's like "The way I deal with the political is that I pretend to have access to the mind of a nine-year old boy in Sudan" (Lerner 2015). ${ }^{8}$

After reading 10:04, we might develop for ourselves, and reflect on, the hypothesis that it could be beneficial for us to develop future-oriented narratives that take into account and value both local, everyday concerns, and considerations about global crises and the future of the planet. While 10:04 does not explicitly provide this hypothesis, some readers might develop it and reflect on it. Readers can compare themselves with the narrator of 10:04, and consider how they, like the narrator, might develop a narrative that balances local and global concerns.

10:04 provides an example of what such a narrative could resemble, giving us the perspective of a narrator who focuses on information and recognizes patterns both in his local circumstances and in global issues. Gibbons argues that fiction has the ability to ask readers to "think historically_to place ourselves within a larger narrative of geo-

${ }^{8}$ James provides this quotation when discussing how Lerner's localist fiction engages with global concerns (2017: 134-135). 
logical time and human evolution" (Gibbons 2019b: 293). This essay contends that, after reading 10:04, some readers might reflect that it is sometimes beneficial to think historically, but that it is also valuable to focus on and care about everyday concerns. Readers might hypothesize about the value of balancing local and global concerns in their personal narratives, and they might choose to adopt a perspective and personal narrative more similar to that of the narrator of 10:04.

Readers might think that the narrator of 10:04 does not do enough to alleviate the world's environmental concerns. Yet the narrator's insufficiency, itself, might prompt readers to actively consider what they could do, themselves, to more successfully address those concerns. If the narrator had no shortcomings, some readers might never reflect on what they could do in comparison. Suppose that, having read 10:04, readers consider the hypothesis that it would benefit them to live more like the narrator than they currently do. Even if readers reject this hypothesis, because the narrator does not do enough to address environmental concerns, the readers' reflections might still have valuably influenced how they see their place in the world. ${ }^{9}$

As Iris Vidmar notes, a hypothesis that we extract from a work of fiction is not valuable only if we determine it true and if it results in us acquiring new knowledge; rather, part of its value is determined by how it impacts the ways we view ourselves and our experiences (2013: 190). Consider novels that present flawed characters and hypotheses that readers reject. In some cases, those novels might lead readers to engage in reflection long after they have finished reading-reflections they might not have had if they had approved of the characters and had agreed with the novels' hypotheses. Such reflections might valuably shape how the readers view themselves and their experiences, in comparison with the novels' characters.

\section{Authoring a fiction, authoring a life}

10:04 is a particularly good example of a novel that highlights the impact that fictions can have on their readers. Lerner notes that 10:04 is meant to reflect in part on "how fiction functions in our real lives" (Lerner 2014B). He adds: "My concern is how we live fictions, how fictions have real effects, become facts in that sense, and how our experience of the world changes depending on its arrangement into one narrative or another" (2014B; cf. Gibbons 2018: 86 and 94). While Lerner might not have had in mind anything quite like what this essay suggests, his thoughts in this quotation are nonetheless relevant.

What makes 10:04 a good example, when exploring the ways in which fictions can affect how we lead our factual lives, is that 10:04 belongs to a literary genre known as "autofiction" (van den Akker, Gib-

${ }^{9}$ Iris Vidmar writes that often the hypotheses "we extract from works ... will not provide definite answers, but will certainly influence the way we think about ... our place in the world" (2013: 190). 
bons and Vermeulen 2019: 48-49; Gibbons 2018: 75-76 and 85). As a work of autofiction, 10:04 mixes elements of autobiography with fiction, and focuses on the relation between them.

As Robin van den Akker, Alison Gibbons, and Timotheus Vermeulen note, the narrator of 10:04 shares the same name as the author (2019: 49), and the novel is a blend of fiction and autobiography, drawing directly from the author's real life and work. For example, according to the novel, the narrator has written a short-story which is included, in full, in 10:04 - a story that is, in fact, a republication of a story that the real-world Ben Lerner had published in The New Yorker titled, "The Golden Vanity" (Gibbons 2018: 85). Like the author, the narrator also undertakes a residency in Marfa, Texas, during which the narrator writes poetry that is identical to that of the author (Lerner 2014a: 172-176). As a result, 10:04 sometimes seems to encourage its audience to see the novel's narrator as the same person as its real-world author (van den Akker, Gibbons and Vermeulen 2019: 49).

That said, in interviews the author is clear about the extent to which 10:04 is a work of fiction. For example, he writes that a children's book which the narrator co-authored with a child he tutors "is based on a book with a great kid I tutored, but the 'Roberto' character doesn't resemble him very much" (Lerner 2014b). Additionally, a central relationship in 10:04 "is the relationship between the narrator and Alex. Alex isn't based on a real person, at least not a single real person" (Lerner 2014b). van den Akker, Gibbons, and Vermeulen write: "Ben in 10:04 flickers between being an inhabitant of a constructed novel and that of a seemingly depthy real world" (2019: 49; cf. Gibbons 2018: 85-86).

10:04 demonstrates our ability to create new narratives for ourselves; Lerner has written a book according to which he, as the narrator, leads a very different life from the one that he, as the author, has lived. The novel is an example of a constructed narrative, invented by a real person which is - at least in a loose sense-about that real person, too. If the narrator did not seem like "an inhabitant of a constructed novel" (van den Akker, Gibbons and Vermeulen 2019: 49), then 10:04 would not be an example of a constructed narrative, and if the narrator did not seem like an inhabitant of a "depthy real world" (van den Akker, Gibbons and Vermeulen 2019: 49), then 10:04 would not be an example of a new narrative that is invented by a real person that is also about that real person.

The novel does not provide a narrative that Lerner could actually choose to act out in real life. Yet there are clear parallels between authoring an autofictional narrative and constructing a future-oriented personal narrative for oneself. In both cases, the individual constructing the narrative is both "a figure within the story and the person writing it" (Lerner 2012). In both, an individual "invents" a narrative that might deviate in part from true descriptions of the real world. ${ }^{10}$

${ }^{10}$ Velleman discusses the role of individuals as inventors of narratives and the relation between personal narratives and fictions (2005: 71-72). 
Consider an individual who, at the end of a day of work, says, "I am going home now," and constructs a mental narrative in which he does, fully intending to follow through. But suppose that, either as a result of weakness of will or outside circumstances, he fails to act out the narrative he developed. Like a work of autofiction, the protagonist of the narrative would in many ways resemble (or be) the author of the narrative, but, like a work of autofiction, many of the narrative's details would differ from reality. ${ }^{11}$ When individuals construct futureoriented narratives according to which they intend to live, they could not know for sure to what extent their narratives resemble autofiction; those individuals could not know if they will successfully live as they intend. Lerner might not have had this sort of comparison between narratives and autofiction in mind, but, in an interview about his story, "The Golden Vanity," which later became part of 10:04, he does remark:

"[T]he author" begins to feel both like a figure within the story and the person writing it-we're both trying to figure out how he can continue ... I'm talking about something intensely lived: How each of us is constantly striving to reorganize mere chronology into some meaningful pattern, to narrate our pasts in a way that makes a future thinkable. The part of the cliché "you're the author of your own life" that I agree with is its implication that our identities are fictions. (Lerner 2012)

Reflecting on 10:04 - and on Lerner's ability to construct a fictional narrative about himself-might encourage readers to consider their own ability to construct new personal narratives, some of which they might aim to put into action in real life. In fact, 10:04 frequently reminds us of our ability to invent narratives for ourselves (van den Akker, Gibbons and Vermeulen 2019: 51), as when the narrator realizes that the story he has told himself, about how he became a poet, does not cohere with his real-life experiences and is based in part on mis-remembered facts (2014a: 110-116; cf. Bilmes 2018: 3). 10:04 also frequently indicates that the future is open to us; there are numerous possibilities to pursue and narratives we can create (cf. Gibbons 2020: 2 and 8-11). For example, the narrator reflects on the possibility of writing a novel in which he will "project myself into several futures simultaneously" (2014a: 4; cf. 194; Bilmes 2018: 6-10; Gibbons 2019a; 2020: 11).

Earlier, this essay suggested that people should view their personal narratives from three different perspectives: that of author, character, and critic. 10:04 reflects on a figure-Ben Lerner-who is all three; he is the author, who sometimes, like a critic, reflects on his own authorial choices, and he is also a character about whom he writes-a character who himself is also an author. 10:04 might also encourage its audience to reflect on how to juggle these three perspectives when approaching their own life narratives.

Insofar as 10:04 encourages audience members to consider the ways

${ }^{11}$ While Velleman does not discuss the notion of autofiction, he does likewise considers this example in relation to the notions of personal narratives, fact, and fiction (2005: 71-72). 
in which their local, personal lives relate to global issues, like global warming and environmental crises, it might encourage readers to consider revising their personal narratives to take these crises into account. Perhaps, as Gibbons suggests is possible for fiction, 10:04 can express: "a refusal to accept the current state of the world, asking readers instead to think critically and defiantly about the ways in which world events are connected and how their own involvement figures in such a world" (Gibbons 2015: 41; cf. van den Akker, Gibbons, and Vermeulen 2019: 52). Perhaps, in order to most effectively address global issues, like the world's environmental crisis, we will also need to revise our personal narratives like this (Gare 1995: Chapter 5; 2001; cf. Kirkpatrick 2014: 60 and 64-65; Corsa 2018: 247-249).

\section{References}

Bilmes, L. 2018. “'An Actual Present Alive with Multiple Futures': Narrative, Memory and Time in Ben Lerner's 10:04." Textual Practice, advance-publication: $1-22$.

Bruner, J. 1991. "The Narrative Construction of Reality." Critical Inquiry 18: $1-21$.

Bruner, B. and Kalmar, D.A. 1998. "Narrative and Metanarrative in the Construction of Self." In M. Ferrari and R.J. Sternberg (eds.). SelfAwareness: Its Nature and Development. New York and London: The Guilford Press: 308-331.

Camp, E. 2009. "Two Varieties of Literary Imagination: Metaphor, Fiction, and Thought Experiments." Midwest Studies in Philosophy 33: 107-130.

Carr, D. 1986. Time, Narrative, and History. Bloomington/Indianapolis: Indiana University Press.

Corsa, A. J. 2018. "Grand Narratives, Metamodernism, and Global Ethics." Cosmos and History: The Journal of Natural and Social Philosophy 14 (3): 241-272.

Davies, D. 2007. "Thought Experiments and Fictional Narratives." Croatian Journal of Philosophy 7 (19): 29-45.

De Bruyn, B. 2017. "Realism $4^{\circ}$. Objects, Weather and Infrastructure in Ben Lerner's 10:04." Textual Practice 31 (5): 951-971.

Dianda, A. 2018. "William James and the 'Willfulness' of Belief." European Journal of Philosophy 26: 647-662.

Elgin, C. Z. 2002. "Art in the Advancement of Understanding." American Philosophical Quarterly 39 (1): 1-12.

Elgin, C. Z. 2007. "The Laboratory of the Mind.” In J. Gibson, W. Huemer, and Luca Pocci (eds.). A Sense of the World: Essays on Fiction, Narrative, and Knowledge. New York and London: Routledge: 43-54.

Farrell, F. B. 2007. "The way light at the edge of a beach in autumn is learned': Literature as Learning." In J. Gibson, W. Huemer, and Luca Pocci (eds.). A Sense of the World: Essays on Fiction, Narrative, and Knowledge. New York and London: Routledge: 246-265.

Gallagher, S. 2011. "Narrative Competence and the Massive Hermeneutical Background." In P. Fairfield (ed.). Education, Dialogue and Hermeneutics. London and New York: Continuum: 21-38. 
Gallagher, S. 2012. "Empathy, Simulation, and Narrative." Science in Context 25: 355-381.

Gallagher, S. 2014. "An Education in Narratives.” Educational Philosophy and Theory 46 (6): 600-609.

Gare, A. 1995. Postmodernism and the Environmental Crisis. London and New York: Routledge.

Gare, A. 2001. "Narratives and the Ethics and Politics of Environmentalism: The Transformative Power of Stories." Theory and Science 2 (1): http://theoryandscience.icaap.org/content/vol002.001/04gare.html

Gare, A. 2002. "Narratives and Culture: The Role of Stories in Self-Creation." Telos 122: 80-100.

Gibbons, A. 2015. “Take that you intellectuals!' and 'kaPOW!': Adam Thirwell and the Metamodernist Future of Style." Studia Neophilologica 87: 29-43.

Gibbons, A. 2018. "Autonarration, I, and Odd Address in Ben Lerner's Autofictioanl Novel 10:04." In A. Gibbons and A. Macrae (eds). Pronouns in Literature: Positions and Perspectives in Language. London: Palgrave Macmillan: 75-96.

Gibbons, A. 2019A. "Metamodernist Futures or 'a Future that Had Never Arrived': Climate Change and Temporality in 10:04.” Paper presented at Metamodernism, Radboud University, Nijmegen, Netherlands.

Gibbons, A. 2019B. "Entropology and the End of Nature in Lance Olsen's Theories of Forgetting." Textual Practice 33 (2): 280-299.

Gibbons, A. 2020. "Metamodernism, the Anthropocene, and the Resurgence of Historicity: Ben Lerner's 10:04 and 'The Utopian Glimmer of Fiction."” Critique: Studies in Contemporary Fiction, advance publication: 1-15.

Goldie, P. 2012. The Mess Inside: Narrative, Emotion, and the Mind. Oxford: Oxford University Press.

Goldman, A.I. 2005. "Imitation, Mind Reading, and Simulation." In S. Hurley and N. Chater (eds.). Perspectives on Imitation: From Neuroscience to Social Science. Vol 2. Cambridge: The MIT Press: 79-93.

Greenwald, A.G., Carnot, C.G., Beach, R., and Young, B. 1987. "Increasing Voting Behavior by Asking People if they Expect to Vote." Journal of Applied Psychology 72 (2): 315-318.

Hutto, D.D. 2016. "Narrative Self-Shaping: A Modest Proposal." Phenomenology and the Cognitive Sciences 15: 21-41.

James, D. 2015. "Worlded Localisms: Cosmopolitics Writ Small.” In L. Platt and S. Upstone (eds.). Postmodern Literature and Race. Cambridge: Cambridge University Press: 47-61.

James, D. 2017. "Transnational Postmodern and Contemporary Literature." In Y. Goyal (ed). The Cambridge Companion to Transnational American Literature. Cambridge: Cambridge University Press: 122-140.

James, W. 1889. "The Will to Believe." In The Will to Believe and Other Essays in Popular Philosophy. New York, London, and Bombay: Longman Green and Co: 1-31.

Kirkpatrick, A. 2014. "Modernity, Post-Modernity and Proto-Historicism: Reorienting Humanity through a New Sense of Narrative Emplotment." Cosmos and History: The Journal of Natural and Social Philosophy 10 (2): 22-77. 
Kivy, P. 2006. The Performance of Reading: An Essay in the Philosophy of Literature. Malden: Blackwell Publishing.

Klein, A. 2015. "Science, Religion, and 'The Will to Believe." HOPOS: The Journal of International Society for the History of Philosophy of Science 5 (1): 72-117.

Lamarque, P. 2007. "On the Distance between Literary Narratives and Real-Life Narratives.” In D. D. Hutto (ed.). Narrative and Understanding Persons. Cambridge: Cambridge University Press: 117-132.

Lerner, B. 2012, June 10. "This Week in Fiction: Ben Lerner." Interview by C. Leyshon. The New Yorker: https://www.newyorker.com/books/pageturner/this-week-in-fiction-ben-lerner

Lerner, B. 2014a. 10:04: A Novel. New York: Faber and Faber.

Lerner, B. 2014b, September 1. "An Interview with Ben Lerner." Interview by T. Lin. The Believer, 110: https://believermag.com/an-interview-withben-lerner/

Lerner, B. 2015, January 3. "People say, 'Oh, Here's Another Brooklyn Novel by a Guy with Glasses." Interview by E. Witt. The Guardian: https://www.theguardian.com/books/2015/jan/03/ben-lerner-1004-novelbooks-interview

MacIntyre, A. 2008. After Virtue: A Study in Moral Theory. Notre Dame, IN: University of Notre Dame Press.

Nelson, H. L. 2001. Damaged Identities, Narrative Repair. Ithaca, NY and London: Cornell University Press.

Novitz, D. 1984. "Fiction and the Growth of Knowledge." In J. Margolis (ed.). The Worlds of Art and the World. Amsterdam: Rodopi: 47-68.

Nussbaum, M. C. 1990. Love's Knowledge: Essays on Philosophy and Literature. Oxford: Oxford University Press.

Robinson, G. C. 2014. "You Live and Learn: Narrative in Ethical Enquiry with Children." Childhood and Philosophy 10 (20): 305-330.

Simecek, K. 2015. "Beyond Narrative: Poetry, Emotion and the Perspectival View." British Journal of Aesthetics 55 (4): 497-513.

Schechtman, M. 2011. "The Narrative Self." In S. Gallagher (ed.). The Oxford Handbook of the Self. Oxford: Oxford University Press: 394-416.

Tollefsen, D. and Gallagher, S. 2017. "We-Narratives and the Stability and Depth of Shared Agency." Philosophy of the Social Sciences 47 (2): 95-110.

van den Akker, R., Gibbons, A., and Vermeulen, T. 2019. "Metamodernism: Period, Structure of Feeling, and Cultural Logic-A Case Study of Contemporary Autofiction.” In D. Rudrum, R. Askin, and F. Beckman (eds.). New Directions in Philosophy and Literature. Edinburgh: Edinburgh University Press: 41-54.

Velleman, J. D. 2005. "The Self as Narrator." In J.P. Christman and J. Anderson (eds.). Autonomy and the Challenges to Liberalism: New Essays. Cambridge: Cambridge University Press: 56-76.

Vice, S. 2003. "Literature and the Narrative Self." Philosophy 78: 93-108.

Vidmar, I. 2013. "Though Experiments, Hypotheses, and Cognitive Dimension of Literary Fiction.” Synthesis Philosophica 55-56 (1-2): 177-193. 
